\title{
Negotiating Science and Liberalism: Medicine in Nineteenth-Century South Australia
}

\author{
K N WHITE*
}

\section{Introduction}

In this paper I document the ways in which the medical profession in nineteenthcentury South Australia negotiated its claims for medicine to be a science. ${ }^{1}$ It is widely accepted that medicine in the nineteenth century linked itself to science and used the cachet of science to improve its social and professional standing. ${ }^{2}$ The literature on this topic moves from the scientistic and technologically determinist ${ }^{3}$ to a more tempered social history perspective which emphasizes the interplay between scientific factors and social processes. ${ }^{4}$ Increasingly, it has been recognized that medical professionalization was also explicitly shaped by the specific forms of state formation in the nineteenth century, and in particular the ways in which the ideologies of liberalism were expressed. ${ }^{5}$

*Dr Kevin White, Department of Sociology, Australian National University, Acton, 0200, ACT, Australia.

An earlier version of this paper was delivered at the Humanities Research Centre, Australian National University, Conference on Natural Sciences and Social Sciences, September 6-9, 1996; and to the Interdepartmental Seminar Series at Victoria University of Wellington, New Zealand, 13 October 1997. I am grateful to the participants at these venues and to Professor Bryan Turner, Dean of Arts, Deakin University, for comments on this work.

${ }^{1}$ Medicine in nineteenth-century South Australia has received remarkably little analysis: see, T L Stevenson, 'Light and living conditions: mortality in nineteenth century Adelaide', Paper to 49th Australia and New Zealand Association for Science, 1979, Conference, Auckland, New Zealand; $\mathrm{S}$ Holton, 'Social medicine in nineteenth century South Australia', Community Health Stud., 1983, 7 (2): 121-35; K N White, 'Aspects of medical professionalisation in nineteenth century South Australia', J. Hist. Soc. S. Australia, 1987, 15: 130-45; K N White, 'Medicine, science and values: 19 th century South Australia and New Zealand', in C Waddell and A Peterson (eds), Just health: inequality in illness, care and prevention, Melbourne and Edinburgh, Churchill Livingstone, 1994, pp. 207-19. For New South Wales, see W Nicol, 'The medical profession in New South Wales 1788-1850', Aust. econ. Hist. Rev., 1984, 24 (2): 115-32; idem, 'Medicine and the labour movement in New South
Wales, 1788-1850', Labour Hist., 1985, 49: 19-38; idem, 'Medical technology in New South Wales 1788-1850', J. Aust. Stud., 1986, 18: 60-74. For Victoria see, E Willis, Medical dominance, Sydney, George Allen and Unwin, 1987.

${ }^{2} \mathrm{~W} F$ Bynum, Science and the practice of medicine in the nineteenth century, Cambridge University Press, 1994. The most generic statement of the role of science in the modernizing process is to be found in G Gurvitch, The social frameworks of knowledge, Oxford, Basil Blackwell, 1971. 'There is no doubt that scientific knowledge occupied first place in [developing] democratic liberal societies . . . the natural and exact sciences had primacy', p. 90.

${ }^{3} \mathrm{~T}$ S Pensabene, The rise of the medical practitioner in Victoria, Canberra, Australian National University Press, 1980. See A W Crosby, Ecological imperialism, Cambridge University Press, 1987, for a generic biologistic interpretation of Western scientific expansion. Analyses more sensitive to the political, economic and social contexts of medicine in the field of medical history are: R MacLeod and M Lewis (eds), Disease, medicine and empire, London, Routledge, 1988; D Arnold (ed.), Imperial medicine and indigenous societies, Manchester University Press, 1988.

${ }^{4} \mathrm{O}$ Temkin, 'The meaning of medicine in historical perspective', in idem, The double face of Janus, Baltimore, Johns Hopkins University Press, 1977, pp. 41-94.

5 L Cowen, 'Liberty, laissez-faire and licensure in nineteenth century Britain', Bull. Hist. Med., 1969, 43: $30-40$. 


\section{$K N$ White}

The developing structure of medical thought in nineteenth-century South Australia illustrates the profession's efforts to be congruent with the political, economic and ideological requirements of a colonial society. Medicine, in its claim to understand the linkage between nature (disease) and society (patterns of illness), performs a political function. The profession mediates the relationship between the individual and society by authoritatively locating some phenomena in the "natural" realm, putting them beyond social and political intervention. This paper highlights the contradictory nature of this process, a contradiction surrounding the idea of what the "individual" is. ${ }^{6}$ On the one hand, the individual is the carrier of personality and of social and political rights and duties; on the other, the individual is the product of the social environment, the target of state administrative bureaucracies, who, in this sense, exists quite independently of his or her own attributes. Liberal theory, and the administration of large urban environments, require that both exist simultaneously. Individuals-as constructions informed by doctrines of individualism and individuality-become explicit entities who are responsible for their own actions, their own bodies and their own diseases. At the same time, the idea of disease as spread by infection allows the profession to conceptualize individuals as individuated entities, as members of at-risk groups, who, by virtue of occupation or geographical location, can be aggregated and administratively surveyed. The state, for its part, forced physicians to reconcile these contradictory understandings by withdrawing support for the profession's claims to monopoly practice when it failed to do so.

Thus medicine found itself involved in these debates as it sought to claim a scientific basis for its explanation of disease in the nineteenth century. As an exercise in historical sociology ${ }^{7}$ this paper does not take for granted the epistemological status of medicine's knowledge, but rather assumes that even what is taken to be factually correct has to be explained in terms of its social location. ${ }^{8}$ Thus medicine's claim to be a science paradoxically provided the state and the public with a weapon against the medical profession, while at the same time aiding the profession itself. The claim that medicine was a science had to be played out in a number of arenas. A significant number of medical practitioners had to be convinced that it was a science. This is illustrated in the debates on homoeopathy and over the introduction of deep drainage. In these disputes the pecuniary interests of physicians intersected with the professional interests of homoeopaths, urban reformers and sanitary engineers. In terms of explanations of disease, the state and the public had to be convinced of the medical interpretation of disease, and competing explanations by urban reformers and sanitary engineers had to be disposed of. At the same time, the administrative requirements of the state were that the population be "numbered", 9 and when the state's interest in administration and surveillance clashed with the interests of the profession, the state rejected the profession's claim to a monopoly of

\footnotetext{
${ }^{6} \mathrm{~N}$ Abercrombie, S Hill, B Turner, Sovereign individuals of capitalism, London, Allen \& Unwin, 1986 pp. 73-86.

${ }^{7} \mathrm{~K}$ Figlio, 'The historiography of scientific medicine', Comp. Stud. Soc. Hist., 1977, 19: 262-86; $\mathrm{K} N$ White, 'Towards a sociology of medical
}

history', Explor. Knowledge, 1987, 5 (1): 33-48.

${ }^{8} \mathrm{D}$ Bloor, Knowledge and social imagery, London, Routledge and Kegan Paul, 1976.

${ }^{9}$ I Hacking, The taming of chance, Cambridge University Press, 1990; D V Glass, Numbering the people, Farnborough, D C Heath, 1973. 


\section{Medicine in Nineteenth-Century South Australia}

the medical market. Any account of the process of medical professionalization in the nineteenth century thus has to incorporate the interaction of theories of disease, the role of the state and the activities of the medical profession. Medicine then will be seen to be a social process and its activities conceptualized in terms of social outcomes.

In providing an account of the interrelationship of the nascent profession and its attempts to reconcile professional formation with liberalism and to meet the needs of the developing regulatory state ${ }^{10}$ there is always a danger of teleology and of anachronism. The charge of teleological argument arises because medicine seems to be over-determined in its transformation into a modern scientific profession. Anachronism results because neither the profession nor medical science, as we understand them today, existed in the nineteenth century, yet we use our concepts to explain nineteenth-century reality. The defence against both these charges is that a nascent profession was in the process of constructing science as a vocabulary on which to justify its status. In this process both "profession" and "science" became central to, but distinct from, the state. Such a development is common to medicine in Western societies generally. In Germany in 1845, Haeser, writing one of the first histories of medicine as a science, explicitly recognized that in doing so he was actively contributing to the professionalizing claims of the occupation. ${ }^{11}$ Similarly in France, and somewhat later, Daremberg used the history of medicine to develop the claim that medicine was a science. ${ }^{12}$ Science then was an argumentative tool used by the occupation quite explicitly to develop its standing. Thus to talk of "science" is not so much an anachronism, as a misnomer: "science" was in the process of being constructed. As Hamlin has demonstrated in his analysis of chemists, nineteenth-century scientists "hoped to sell authority: they would become members of Coleridge's clerisy, the profession on which society depended for the cultural authority over certain problems and they claimed epistemic warrant for that status.... [the process was] one of aggressive and successful discipline promotion, the struggle of a group of experts to acquire authority, regardless of the state of their art at the time". ${ }^{13}$

\section{Medicine, Science and the Colonial Environment}

The Province of South Australia was founded against the background of Chartist principles with the aim of providing a non-antagonistic environment for capitalists and labourers. ${ }^{14}$ So as to prevent the development of any widespread sense of inequality in its society, the cost of land was set at a level that would make it ultimately purchasable by hard-working labourers. The non-mercantile middle classes-and particularly the profession of medicine-had difficulty in finding a niche in this social structure. Edward

\footnotetext{
${ }^{10}$ On the state, see O MacDonagh, A pattern of government growth 1800-1860, London, MacGibbon and Kee, 1961.

"H Haeser, Lehrbuch der Geschichte der Medicin, Jena, Friedrich Mauke, 1845.

${ }^{12} \mathrm{C}$ Daremberg, Histoire des sciences médicales: comprenant l'anatomie, la physiologie, la médecine, la chirurgie et les doctrines de pathologie générale, 2 vols, Paris, J-B. Baillière et Fils, 1870. For discussion of this source and note 11 , see J Burnham,
}

'How the concept of profession evolved in the work of historians of medicine', Bull. Hist. Med., 1996, 70 (1): 1-24, pp. 5,7 .

${ }^{13} \mathrm{C}$ Hamlin, A science of impurity: water analysis in nineteenth century Britain, Bristol, Adam Hilger, 1990, p. 3.

${ }_{14} \mathrm{~J}$ Moss, Sound of trumpets: history of the labour movement in South Australia, Netley, Adelaide, Wakefield Press, 1985, pp. 1-12. 


\section{KN White}

Wakefield, the ideologue of the founding fathers, had envisaged a class of "clergymen, lawyers or doctors . . . respectable people in the sense of being honourable, of cultivated mind and gifted with the right sort and right proportion of self-respect". ${ }^{15}$ However, neither the economy nor the social structure was strong enough to support such a group while they pursued a professional life. Those medical practitioners leaving England to escape unemployment - "tutored by disappointment for colonial ventures"16_did not find a ready-made environment in which their services were required. As Dr Handasyde Duncan warned doctors in 1850: "For the great majority a hopeless prospect is offered of being able to command the ordinary comforts of life, or of being able to mix in the society to which in their youth they had become accustomed". ${ }^{17} \mathrm{He}$ went on to recommend that they look to agriculture as a gainful occupation until the population increased sufficiently to support them. ${ }^{18}$

In response to this situation, many medical practitioners mixed a business with a professional ethos. ${ }^{19}$ This worked to their overall advantage; in practising agriculture, sheep farming, and by joining parliament, manufacturing bricks and milling flour, members of the profession established a high public profile for medicine as well as instituting links with the gentry. Other medical practitioners founded wineries as adjuncts to their practices: Dr Alexander Kelly, Tintara; Dr Christopher Lawson, Penfolds; and Dr W Angoves, Angoves Wines. ${ }^{20}$ They were perceived as medical practitioners, "who did valuable work in many directions in fostering community interests". ${ }^{21}$ Thus the medical practitioner traded on his status as a learned man, fulfilling social-control roles in the new society. Because of his status as a non-labouring gentleman he had access to social and political power. ${ }^{22}$ It was his class position that allowed the doctor to take up such posts as Protector of Aboriginals, Inspector under the Education Act, or Immigration Officer, and to develop his social standing as well as a patronage network by treating the important and powerful. ${ }^{23}$ For example Handasyde Duncan was Immigration Officer at Port Adelaide from 1850-1878. He was also on the Board of the Church of England Boys School, St Peter's College, which had been founded by South Australia's first medical practitioner, Dr John Woodforde. ${ }^{24}$ As Duncan's biographer commented, "although he became a civil servant, he was in fact on equal terms with the gentry who made up the first colonial parliaments through his friendship with many of them". ${ }^{25}$

${ }^{15}$ E G Wakefield, $A$ view of the art of colonisation, London, Parker, 1849, pp. 135-6.

${ }^{16}$ D Pike, Paradise of dissent: South Australia 1829-1857, London, Cambridge University Press, 1957 , p. 12.

17 H Duncan, The colony of South Australia, London, T \& W Boone, 1850, p. 18.

18 Ibid., p. 23.

19 J B Cleland, Pioneer medical men in South Australia, Pioneers Association of South Australia Publications, 1935-49, 1 st Series.

20 J T Hagger, Australian colonial medicine, Adelaide, Rigby, 1979, p. 43; South Australian Branch of the British Medical Association The South Australian Branch of the British Medical Association: a centenary history, Adelaide, SABMA, 1979.

\section{${ }^{21}$ Royal Geographical Society of South} Australia, The centenary history of South Australia Adelaide, Royal Geographical Society of South Australia, South Australian Branch, 1956, p. 345.

22 See, for example, C Lawrence,

'Incommunicable knowledge: science, technology and the clinical art in Britain 1850-1914', $J$. contemp. Hist., 1985, 20 (4): 503-21.

${ }^{23}$ M A Barbalet, The Adelaide Children's Hospital 1876-1976, Adelaide Children's Hospital, 1975 , p. 21.

24 South Australian Branch of the British Medical Association, op. cit., note 19 above, p. 2.

25 P Gifford, 'Dr Handasyde Duncan', J. hist. Soc. S. Australia, 1985, 13: 91-100, p. 91. 


\section{Medicine in Nineteenth-Century South Australia}

This type of advancement was reflected institutionally in the profession's representation on boards such as the University of Adelaide Council. On the first Council, established in 1874 , there were two medical practitioners; by 1877 one quarter of its members were medical men. ${ }^{26}$ This strategy of professional advancement through social achievement ${ }^{27}$ was also reflected in membership of shared interest groups such as the South Australian Literary Association of which a doctor, Edward Wright, was a founding member. ${ }^{28}$

The struggle by the medical profession in the nineteenth century to gain autonomy over its work through state legislation and to consolidate its status relied not only on social achievements but also on an appeal to its knowledge base-to its scientificity. It should be remembered that in the 1870 s and 1880 s "scientists were idolised as the intellectual heroes of the day who would ultimately sweep away all human misery"29 _ and who on this basis should play a large and unquestionably legitimate role in public affairs. As the report of Dr Sylvanus Magarey's review of medical progress since 1844 given to South Australia's Legislative Council shows:

Without for one moment attempting to disparage the brilliancy and mental acumen and the wonderful application of the profession prior to 1844 he [Dr Magarey] might fairly remind honourable members that the last fifty years had witnessed a vast change in the practise and knowledge of medicine (Hear, hear) what with the gain to the community with the use of chloroform, ether and other anaesthetics, the more thorough study of anatomy, the wonderful progress of the knowledge of physiology, the aid rendered by comparative anatomy and biology; what with the discovery of electricity and magnetism and its application to physiological investigations and to medical and surgical treatments; what with the progress of chemistry, and in point of fact many other sciences - the growth of the scientific knowledge of medicine had been enormous. ${ }^{30}$

"With all this advance" he concluded "it would be strange indeed if the status of the profession did not rise pari passu". It is true that the attachment to science facilitated professionalization: "By forcing the rhetoric of science into the social vocabulary of the period, physicians secured a vehicle for their professional recognition". ${ }^{31}$ However, what has to be clearly recognized is that it was forced: the rhetoric of science was not easily accepted by medical practitioners themselves or by representatives of capital, and it was often rejected by the state, and resisted by the urban population.

In South Australia, particular members of the medical profession explicitly linked their medical background to natural science, though with limited impact on their public standing. For example, Dr Edward Stirling described the marsupial mole; Dr Joseph Verco pursued an academic interest in conchology; Dr A M Maude described native birds; Dr R

\footnotetext{
${ }^{26}$ A A Lendon, 'The Medical School of South Australia', S.A. Public Library Archives, (no date.) No. 1130 m., p. 13.

${ }^{27}$ For a comparison with the English case, see I Inkster, 'Marginal men: aspects of the social role of the medical community in Sheffield, 1790-1850', in $\mathrm{J}$ Woodward and D Richards (eds), Health care and popular medicine in nineteenth century England, London, Croom Helm, 1977.

$28 \mathrm{~J} \mathrm{~J}$ Pascoe, History of Adelaide and vicinity: with a general sketch of the men, Adelaide, Mussey and Gillingham, 1901, p. 443.
}

${ }^{29}$ G Basalla, W Coleman and R H Kargon (eds), Victorian science, New York, Anchor Books, 1970, p. 5; see also E Hobsbawm, 'From social history to the history of society', Daedalus, 1971, 100 (1): $20-45$, p. 29.

${ }^{30}$ South Australia Parliamentary Debates (hereafter SAPD), 1889, 5 Nov.: 1420.

${ }^{31}$ S E D Shortt, 'Physicians, science, and status: issues in the professionalization of Anglo-American medicine in the nineteenth century', Med. Hist., 1983, 27 (1): 51-68, p. 62. 
$\mathrm{H}$ Pulleine, spiders and aboriginal lore; while Professor Wood-Jones developed comparative anatomy and anthropology. ${ }^{32}$ More significantly, the profession sought to convince the public of the worth of its knowledge by providing public lectures in which science and medicine were interlinked. Dr Allan Campbell, for example, delivered public lectures and published essays on matters of health: on bringing up a baby; ${ }^{33}$ on tuberculosis $;^{34}$ on the people's health; ${ }^{35}$ and on sewage and deep drainage. ${ }^{36}$

Despite these efforts to link itself with science, the profession met with considerable obstacles. In the first place, the colonial environment provided quite a different context for science to that of Europe. In a dissenting, Chartist province, claims to being learned were not sufficient to establish the profession. As Douglas Pike pointed out: "A learned profession was not enough to win respectability: it was often a handicap. Status in law, church and medicine implied privilege of an esoteric kind that was bitterly resented". 37 Thus in a environment in which the establishment of a viable existence was of major concern to the population, and controlling public expenditure the overriding concern of the state, science received a luke-warm reception. As a historian of Australian science has remarked: "In general the citizenry was antipathetic to science. More importantly, colonial governments, straining for economic and social stability were indifferent-if not openly hostile-to the support of science". 38

It has been reported, for example, that Adelaide's public library, with 81,000 volumes in the $1870 \mathrm{~s}$, held no medical books. ${ }^{39}$ At the same time there was popular resistance to the introduction of medical training in the colony. In fact, it was only following a bequest in 1884 that the University of Adelaide established a medical school, and that an Anatomy Bill was introduced in the Legislative Council. ${ }^{40}$ A Surgery Bill allowing Adelaide University to confer degrees was introduced and passed in $1888 .{ }^{41}$

The debates over these Bills were brief, but provide important evidence of popular resistance to medicine. They were highly emotive, raising a range of complex problems about the role of medicine as a moral arbiter of the person, not only in life, but in death. ${ }^{42}$ The Anatomy Bill, for instance, proposed that the bodies of persons dying in any public institution should be made available for anatomical studies, unless the person or relatives expressed a contrary wish. ${ }^{43}$ It was argued that the provision should not apply to those dying in hospitals. ("Of course it would be wrong to destroy public confidence in the hospitals".) But there was nothing against the use of dead asylum or gaol-inmates- "for the more they induced people to keep out of gaols the better it would be . .."44. Sickness

\footnotetext{
32 Royal Geographical Society of South Australia, op. cit., note 21 above, p. 347.

${ }^{33}$ A C Campbell, How to manage a baby, a lecture delivered at the City Mission Hall, Adelaide on 6 June, South Australian Public Library, 1878.

${ }^{34}$ A C Campbell, Tuberculosis, inaugural address to S.A. Institute of Hygiene and Bacteriology, Adelaide, W K Thomas, 1898.

${ }^{35}$ A C Campbell, 'The people's health, interesting notes and suggestions', The S.A. Registrar, 1898, January.

${ }^{36}$ A C Campbell, 'The sanitary aspects of the deep drainage system of Adelaide', held in South Australian Public Library, Z628, no date.
}

\author{
${ }^{37}$ Pike, op. cit., note 16 above, p. 510. \\ ${ }^{38}$ A M Moyal (ed.), Scientists in nineteenth \\ century Australia, Melbourne, Cassell Australia, \\ 1976, p. 4. \\ ${ }^{39} \mathrm{G}$ Richards, The advantages of Adelaide, \\ Adelaide, J H Sherring and Co., 1914, p. 53. \\ 40 SAPD, 1884, 9 Sept.: 910. \\ 41 SAPD, 1888, 4 and 5 Dec.: 2007; 2008. \\ 42 For England, see J Knott, 'Popular attitudes to \\ death and dissection in early nineteenth century \\ Britain', Labour Hist., 1985, 19: 1-19. \\ ${ }^{43}$ SAPD, 1884, 23 Sept.: 1078. \\ 44 SAPD, 1884, 16 Sept.: 987.
}




\section{Medicine in Nineteenth-Century South Australia}

was not a culpable offence; but destitution or imprisonment was not only clear evidence of culpability but also, in a sense, of a dehumanization that forfeited a body in death.

The fear of anatomical dissection was not restricted to the destitute, and as late as 1895 concern that there was a dissection-mania in the Adelaide hospital was reflected in Parliament. The case was cited of a young man dying within eight hours of being admitted:

... and when his friends inquired for his body they had difficulty in obtaining it. When they saw it in the dead house they found that a surgical demonstration had taken place and the body, as one of the witnesses stated, it was like a "mass of meat ready for the sausage machine". They could only obtain the body after getting a magistrate's order, and even then they could not be sure that they had obtained the whole body. 45

A second case was documented in the same debate relating to the death of a woman:

On the Sunday that she was to be buried the man brought in his children to see the last of their mother, but when he went into the dead house he found the body had been ripped to pieces, sewn up with a piece of bagging twine, and thrown into a coffin without a shroud-to be buried like a dog and it was horrible that such a state of affairs should exist. ${ }^{46}$

There was also resistance to the profession's attempts to medicalize what had previously been part of the normal life cycle, namely death. In 1889 Sylvanus Magarey introduced a clause into the Medical Act Amendment Bill of 1869 (Act 471) to restrict the writing of death certificates to qualified medical practitioners. Opponents of the clause claimed that this was "only adding more terrors to death, that it should be necessary for a gentleman with a long string of letters after his name to certify the cause of death ... It simply meant driving the business into the hands of the legal medical practitioners". ${ }^{47}$ While the clause was passed, the issue was not resolved in practice and until the end of the century questions were raised about whether coroners were accepting death certificates from unqualified practitioners. ${ }^{48}$

The profession also ran up against exasperated state administrators who sought to introduce order into the cause of death classification and the wide-ranging vocabulary of disease. Take, for example, the resolution of the deficiencies of nineteenth-century medical terminology. There were forty-four synonyms for typhoid fever, thirty-nine for enteric or pythogenic fever, and seven for simple continued fever (the diagnosis of an indefinite group of symptoms). ${ }^{49}$ Notifiable diseases included, along with bubonic plague, ${ }^{50}$ smallpox, cholera, diphtheria, membranous croup, erysipelas, diseases known as scarlatina or scarlet fever, and the fevers known as typhus, typhoid enteric, relapsing or puerperal, and any others declared by the governor in council. ${ }^{51}$ Public Health legislation specified epidemic, endemic, infectious and contagious diseases, despite the recognized "difficulty in saying where one ended and the other began". 52 In other words, it is as difficult for us to know, in any sense which specifies diseases as discrete biological entities, what nineteenth-century medicine was referring to, as it was to those at the time.

${ }^{45}$ SAPD, 1895, 29 Nov.: 2451.

46 Ibid.

47 SAPD, 1889, 3 Dec.: 1808-9.

48 SAPD, 1895, 10 Dec.: 2643.

$49 \mathrm{~J} \mathrm{H}$ L Cumpston and F McCallum, The history of intestinal infections (and typhus fever) in
Australia, 1788-1923, Canberra, Commonwealth of Australia, Department of Health Service Publication, No. 36, 1927, pp. 10, 21-29.

50 SAPD, 1894, 6 Dec.: 2725.

${ }^{51}$ SAPD, 1896, 13 Oct.: 221.

52 SAPD, 1873, 11 Sept.: $403-4$ 


\section{KN White}

As the Queensland Registrar General, trying to consolidate the cause of death category on death certificates, put it:

In reply to those gentlemen who do not approve of the particular classification of disease employed ... to depart from it to suit the ideas of individual medical gentlemen would be to sacrifice the great and certain advantage of a unity of classification to the vain hope of drawing up a form that would please all, the subject being one in which perfect unanimity is impossible. ${ }^{53}$

In short, where the profession could not resolve its scientific disputes the state resolved them for it by drawing on Imperial medical classifications, which were regularly revised towards greater specificity. ${ }^{54}$

In addition to disputes over the scientific knowledge base of medicine, the professionalization of medicine in nineteenth-century South Australia came into conflict with the political ideology of classical liberalism. Liberalism as transplanted to Australia was distinctive in that the state had a large part to play in the constitution of the economy and of society. ${ }^{55}$ As one commentator has put it, "the state, far from encroaching upon individual rights, would be the most likely protector of rights against other agencies of social coercion. Australians believed that the major constraints on individual liberty were not public but private". 56 In this regard they shared classical liberalism's suspicions of professional cartels and of organized business interests. However, classical liberalism's laissez-faire theory of the state found little resonance with this understanding of liberalism in which the state secured individual rights and autonomy. ${ }^{57}$

In the context of the Province of South Australia, the state had an ipso facto legitimacy to participate in the affairs of society. Nor was its role a circumscribed one, as is usually characteristic of laissez-faire theories and practices of the state. ${ }^{58}$ Nineteenth-century political theory in Australia was informed by old liberalism, new liberalism, utopianism and anti-utopianism. ${ }^{59}$ Old liberalism, deriving from Benjamin Kidd, was a form of solidarist Darwinism, which argued that it was groups, not individuals, which competed for survival. The strength of any nation depended then on the health of its working class. This in turn led to a focus on the physical and medical aspects of the different classes and for calls for state intervention to protect the health of the citizens. ${ }^{60} \mathrm{New}$ liberalism was a

\footnotetext{
53 Cumpston and McCallum, op. cit., note 49 above, p. 19.

54 See MacLeod and Lewis (eds), op. cit., note 3 above; T Johnson, 'Imperialism and the professions: notes on the development of professional occupations in Britain's colonies and the new states', in P Halmos (ed.) Professionalisation and social change, Sociological Review Monograph No. 20, University of Keele, 1973, 20, pp. 281-309.

$55 \mathrm{~N}$ Butlin, 'Some perspectives on Australian economic development, 1890-1965', in C Forster (ed.), Australian economic development in the twentieth century, London, Allen \& Unwin, 1970, pp. 266-327; S Glynn, Urbanisation in Australian history, 1788-1900, Melbourne, Thomas Nelson, 1975.

${ }^{56} \mathrm{R}$ Rosecrance, 'The radical culture of Australia', in L Hartz (ed.), The founding of new societies, New York, Harcourt Brace, 1964, p. 310.
}

\footnotetext{
${ }^{57}$ See, G de Ruggiero, The history of European liberalism, trans. R G Collingwood, London, Oxford University Press, 1927, p. 134.

$58 \mathrm{~J}$ Roe (ed.), Social policy in Australia: some perspectives 1901-1975, Stanmore, NSW, Cassell Australia, 1976, p. 6.

$59 \mathrm{~J}$ Docker, 'Can the centre hold? Conceptions of the state 1890-1925', in Sydney Labour History Group, What rough beast? The state and social order in Australian history, Sydney, Allen \& Unwin, 1982, pp. 57-78; see also, C Campbell, 'Liberalism in Australian history: 1880-1920', in Roe (ed.), op. cit., note 58 above, pp. 24-34.

${ }^{60}$ The logic of this position may not lead to a concern for working-class welfare, but to eugenics. Cf. R Hofstadter, Social Darwinism in American thought, New York, Braziller, 1965. See quotation in text at note 124 of this paper.
} 


\section{Medicine in Nineteenth-Century South Australia}

conservative reaction to the erosive social consequence of the development of the market as a principle on which to base social solidarity, calling on the state to guarantee the minimum conditions for the development of the common good. Utopian socialists operated with a model of society as the "great trust", in which all worked co-operatively for the state. The anti-utopians, on the other hand, argued that evolution is not necessarily progressive and called for the state to intervene to lessen the gap between the rich and the poor. The diversity and, indeed, the inherent contradictions of these intellectual trends in Australian politics need not detain us here. Rather, the point is to note what they all had in common: the call for overt state action which was not regarded as illegitimate. ${ }^{61}$

These different conceptions of the state's place in civil society resulted in its playing a dominant role in the economy. ${ }^{62}$ Indeed it was quite common for nineteenth-century visitors to Australia and New Zealand to focus on the "state experiments" in the colonies. ${ }^{63}$ The state actively excluded individual entrepreneurs from the establishment of railways and telegraphs, itself providing durable assets, and it was the biggest employer of labour, as well as the leading borrower on London's capital markets. ${ }^{64}$ Thus in the Australian setting there was, as Butlin has argued, "a persistent functional relationship" 65 between the public and the private sector, resulting in a situation best described as "colonial socialism". 66 This set of political theories, as well as their practical outcomes in economic terms, had a decisive influence on the development of the professions in the colonies-a situation which has not yet been examined. ${ }^{67}$

Medicine's attempts to turn health and illness into scientific matters, also confronted the individualism of liberalism. The following quotations from an article by $\mathrm{Dr}$ James Jamieson, show the restriction that medicine as liberalism placed on medicine as science in its aetiological understanding of disease:

I fear we are not ripe for legislative action with reference to epidemics, which would be tolerably efficient, and all on account of the craze we are possessed with about the liberty of the subject ... the liberty at present enjoyed of scattering the poisons which produce epidemic diseases is no right liberty at all, but a misdemeanour, if not a crime. . . ${ }^{68}$

It is very likely that many think that little can be done in the way of preventing consumption in a given locality, by other measures than those the individual may take for the preservation of his own health ... [however] the number of deaths from consumption in a town or district can be reduced greatly by the adoption of general sanitary improvements, independent altogether of what each delicate person may do for himself. ${ }^{69}$

${ }^{61}$ B Brugger and D Jaensch, Australian politics: theory and practice, Sydney, Allen \& Unwin, 1985, pp. 8-13, provide a discussion of the populist underpinnings of these positions.

62 Butlin, op. cit., note 55 above, pp. 266-327. Glynn, op. cit., note 55 above.

${ }^{63} \mathrm{~W}$ Pember-Reeves, State experiments in Australia and New Zealand, London, Richards, 1902.

${ }^{64}$ Butlin, op. cit., note 55 above, p.38; N Butlin, Australian domestic product, investment and foreign borrowing 1861-1938/39, Cambridge University Press, 1962.

${ }^{65}$ Butlin, op. cit., note 55 above, p. 47.

${ }^{66} \mathrm{~N}$ Butlin, A Barnard, and J Pincus,
Government and capitalism, London, Allen \& Unwin, 1982.

${ }^{67}$ M Ramsey, 'The politics of professional monopoly in nineteenth-century medicine: the French model and its rivals', in G L Geison (ed.), Professions and the French state, 1700-1900, Philadelphia,

University of Pennsylvania Press, 1984, pp. 225-305, has provided an outstanding account of the European variants of liberalism and their impact on the formation of the medical profession.

$68 \mathrm{~J}$ Jamieson, 'Diseases which should be prevented', Melbourne, Australian Health Society, Sanitary Tracts, 1882, 1 st Series, No. 8, pp. 9-10.

${ }^{69}$ Ibid., p. 12. 


\section{KN White}

These two passages sum up the paradox confronting medicine in nineteenth-century liberal capitalist societies. To be congruent with liberal ideology it had to focus on treating the singular individual and to separate the individual from the social environment. At the level of medical theory this meant the individual had to held responsible for his or her own illnesses. At the same time, empirical medical investigation was making it very clear that individuals as such did not produce disease. Rather, the social environment in which they lived both produced and spread disease. However, social explanations of disease causation challenged the interests of entrepreneurs and developers, bringing onto the political agenda the control of the urban environment and, in particular, factories and the urban slums. Social explanations also brought the state into the picture as a mediator of class relations, modifying the urban environment and the impact of the manufactories on workers' health. Professionalizing medicine was therefore caught in a paradox. It explained disease in individual terms but it was confronted with the social patterning of disease. The state for its part was interested in the individual-in terms of monitoring and surveillance. From its point of view, medicine had to produce aggregate data on births and deaths. Medicine, then, was involved in the paradox of simultaneously constructing and undermining the individual.

\section{Homoeopathy}

The contradictions between liberalism and professionalism were played out in the disputes between allopaths and homoeopaths in nineteenth-century South Australia. The case of Dr G Bollen, a German practitioner with American qualifications in homoeopathy, illustrates how the allopaths' attempts to restrict unqualified practice led to a challenge of their claim to a coherent knowledge base. The state mediated the conflict by partially supporting the allopaths, and simultaneously allowing the registration of homoeopathic practitioners, thus granting them de jure formal medical qualifications.

The South Australian Act of Parliament, Number 17 of 1884, set out the conditions for legally-qualified medical practitioners. The Governor appointed a Medical Board of three to whom candidates had to show a university qualification in medicine, while surgeons had to have membership of a Royal College. Members of the Company of Apothecaries had been excluded from practice by Act Number 1 of 1846. A Medical Register was to be drawn up and the Board was to dispense certificates of practice, provided the prescribed conditions were met, for the price of one guinea.

While these Acts were in force they had little impact on the state's employment policies. They were not reflected either in the policies of the South Australian Branch of the British Medical Association and, despite the best attempts of the reformers of the profession, were unenforceable. ${ }^{70}$ Indeed, in the public arena the profession could do little more than express indignation about unqualified practice. The Fifteenth report of the Central Board of Health stated:

... a letter from an unqualified practitioner seeking advice and information in reference to diphtheria and as being what time must elapse after the development of the disease before the danger

\footnotetext{
${ }^{70}$ White, 'Aspects of medical

professionalisation', op. cit., note 1 above,

pp. $130-43$.
} 


\section{Medicine in Nineteenth-Century South Australia}

of contagion is over and how long the disease takes to develop. The local board was informed [by the Central Board] that a qualified practitioner would be guided by the circumstances and would act on his own judgement in such cases. ${ }^{71}$

The response would have been unlikely to deter anyone from unqualified practice, nor was the implied access to privileged knowledge very impressive. However, in very important ways the problem of unqualified practice was raised by members of the profession who practised homoeopathy. Two practitioners, Dr Allan Campbell and Dr Sylvanus Magarey, entered Parliament (Campbell for over twenty years) as the profession's representatives. Campbell, described by an early twentieth-century writer as "the leading exponent of this now extinct heresy", 72 established the Adelaide Children's Hospital in 1879 and set up the first bacteriological laboratory in Adelaide. Dr Joseph Verco, a leading practitioner in Adelaide for thirty years and founder of one of Adelaide's largest family medical dynasties $^{73}$ was accused by other doctors of unprofessionalism on his return from the London Hospital with the Gold Medal because he was Magarey's cousin. Thus homoeopathy was a significant issue for the profession, particularly as there was no clear way of choosing between homoeopathy and allopathy. As has been noted, "the patients of the homoeopaths died of the disease and the patients of the allopaths died of the cure". 74

The attempt to restrict homoeopathic practice opened up divisions within the ranks of the profession in terms of the illiberalism of professional closure. Liberalism, as it relates to science, emphasizes "impartiality in judgement, tolerance, criticism [and] obedience to logical rules" ${ }^{75}$ In general, the critique of homoeopathy met only one of these criteria: criticism. Members of the profession were aware of this and were equally concerned that their rights to practise as they saw fit, or to practise profitably, should not be curtailed. Witness the ambivalence (in 1883) of the allopaths to criticizing the homoeopaths in the proceedings of the South Australian Branch of the British Medical Association. Dr Wigg of Norwood was reported to the Branch for practising homoeopathy. He defended himself by arguing that he practised it when the situation, or the request of a patient, justified it. The Association acknowledged his defence, arguing that many practitioners labelled themselves homoeopaths "merely as a trading sign", ${ }^{76}$ and the complaint was withdrawn. A motion was moved "that no medical man, meeting homoeopaths in consultation, can be, or become a member of the South Australian Branch of the British Medical Association". 77 This too was withdrawn. It was argued that "it would in all probability, be injurious to the best interests of the profession, if active opposition was shown to any objectionable form of practice . . The true attitude was simply to ignore it": ${ }^{78}$

Whatever might have been the attitude of the profession in the past there was no desire on their part to prevent any practitioner from adopting any system of treatment that he thought it his duty to support ... The progress of the medical profession had been to very largely, if not completely, demolish arrogance and intolerance-and hence no demand was made but that when a man was

\footnotetext{
${ }^{71}$ South Australia Parliamentary Paper, Fifteenth report of the Central Board of Health, No. 91, 1889, p. 9.

72 Lendon, op. cit., note 26 above, p. 28.

$73 \mathrm{~J}$ Verco, Masons, millers and medicine, James Crabb Verco and his sons, Adelaide, Lutheran Publishing House, no date.
}

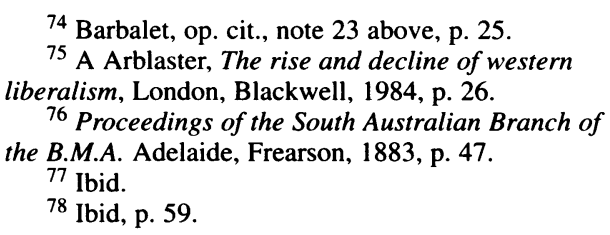




\section{$K N$ White}

placed upon the list of legally qualified medical men it should be to afford some guarantee that he knew thoroughly those rules of his art and those principles of his science that were essential. What method of treatment he then adopted was a matter for his own conscience. ${ }^{79}$

What was to become the Bollen case appeared on the Parliamentary agenda in 1879 when Mr Basedow asked if a graduate of any university was entitled to be a legally qualified medical practitioner in the colony. The Attorney-General replied that under the Act No. 17 of 1844 (which defined the qualifications of practitioners) this was the case, but that it was up to the Medical Board to grant a Certificate of Practice. ${ }^{80}$ When the Board did not recognize the qualifications of practitioners from Germany and other countries, in 1880 the Attorney-General introduced a Medical Bill to clarify the situation, stating that what was at issue was not disputes between medical practitioners, but the protection of the public from unqualified practitioners. ${ }^{81}$ In seconding the motion, John Cotton, while supporting the Attorney-General's argument that the public should be protected, also pointed out that the public was in large measure happy with the existing situation. The Bill "would affect people who, although not duly qualified, had the confidence of a large portion of the public. If they [the government] were to prohibit these men from practising they would be doing a great injury to a large section of the community". ${ }^{82}$

Note the situation in which the profession found itself. As a result of the actions of the Board, it was in full confrontation with the state, while at the same time its attempts to deregister homoeopaths. went against strong public interest. The Bill was also opposed on the grounds that there were no criteria on which to evaluate the various branches of medicine-"there were men of eminence in the medical world who knew perfectly well that medical science was still an obscure one". ${ }^{83}$ The Attorney-General, therefore, decided to strike out every debatable point in the Bill, so that overseas practitioners could be registered in South Australia.

The Medical Board still refused to register Dr Bollen and, in 1881, the issue was reopened with a call for all the correspondence on Bollen's case to be tabled in Parliament. ${ }^{84} \mathrm{~A}$ motion was subsequently moved by Mr Mattison, "that in the opinion of this House Mr G Bollen of Pt. Adelaide is entitled to a certificate as a legally qualified medical practitioner". ${ }^{85}$ The Act of 1880 , it was pointed out, provided that any graduate of any medical college who was entitled to practise and hold a government appointment in their own country was qualified to be registered by the South Australian Medical Board. Bollen had qualified at Hahnemann College in Chicago, had been in practice for eleven years, and had the largest practice in Port Adelaide, being attached to nine benefit societies. ${ }^{86}$ In outlining Bollen's background, and in evaluating the Medical Board's response to the request for Bollen's registration, Mattison "came to the conclusion that the Medical Board of S.A. would not carry out any Act of Parliament unless it was agreeable

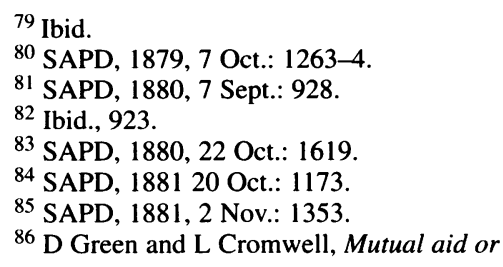

welfare state: Australia's friendly societies, Sydney, Allen \& Unwin, 1984, provides a thorough account of the medical profession's attack on friendly societies but omits divisions within the profession. Thus there is no discussion of the fact that the benefit societies were often the financial base of homoeopathic practice. 


\section{Medicine in Nineteenth-Century South Australia}

to them". ${ }^{87}$ As far as he could see the medical profession's interest in the 1880 Medical Act was to secure "such a practice as their own skill could not procure for them". 88

Mattison lost his motion because his supporters were reluctant to enter into the internal disputes of the medical practitioners; while the Board's supporters maintained that if Bollen was unhappy he could appeal to the Supreme Court and that the Board "were at least as well worthy of respect as Dr Bollen was". ${ }^{89}$ Cotton's view of the case was reported as follows:

So far as he had seen from the documents, he thought the Medical Board should have recognized Dr Bollen but they had set their face against him. (An hon. member-Homoeopathy). He knew there had been great prejudice against homoeopathic schools; but while not discussing the merits of the various schools of medicine he hoped the House would not be asked to express an opinion. ${ }^{90}$

In 1889 Bollen appealed to the Supreme Court, which recognized his qualifications. The members of the Medical Board resigned and stated that, while the Act remained as it was, no other medical practitioners would be found to replace its members.

At the outset, the government took a strong stand against the medical profession. In the Legislative Council, in answer to a series of questions, the Chief Secretary, Dr John A Cockburn, spelt out its position. The government would ask the Board to reconsider its decision. It did not intend amending the Act and if the Board persisted in its stand the government would probably appoint a Board consisting of government officials. ${ }^{91}$ Further, in replacing the Board the government saw no need to amend any existing legislation. ${ }^{92}$ However, on 3 October Cockburn announced the government's intention to repeal the clause allowing registration of overseas qualifications which had led to the resignation of the Medical Board. ${ }^{93}$ Introducing the Medical Act Amendment Bill in the House of Assembly, Cockburn argued that it had two implications. First, it gave the Board discretionary power over the recognition of foreign diplomas and would "prevent the worst diplomas in the world being a qualification here". Second, the government could now rely on qualified medical men to generate the colonies' vital statistics. ${ }^{94}$ The Bill was not an attempt to prevent unqualified practice, nor was it framed in the interests of the profession for: “. . . although a strong protectionist in every other direction [Cockburn] was a free trader on the question of whom a person should be allowed to employ in cases of disease". ${ }^{95}$ In the debate, Magarey prefaced his comments with a disclaimer that the Board's action had anything to do with the recent Bollen case. As he pointed out, the court's decision had gone in Bollen's favour-allowing him to register and practise-and there was little to be said about it. Combining self-righteousness with threat he stated:

The Medical Board having to administer an imperfect Act had very properly resigned and if the Bill as introduced by the government was accepted the difficulty would be solved. If not, a feeling of irritation and a sense of injustice must necessarily rankle in the breasts of medical men. ${ }^{96}$

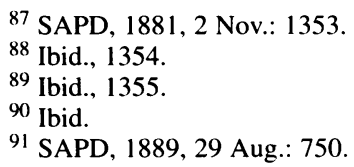

92 SAPD, 1889, 20 Sept.: 1822.

93 SAPD, 1889, 2 Oct.: 1086; 3 Oct.: 1102.

${ }^{94}$ SAPD, 1889,12 Nov.: 1518.

95 SAPD, 1889,19 Nov.: 1608.

96 SAPD, 1889, 5 Nov.: 1421. 


\section{$K N$ White}

Other members of the House did not support these assertions. There was concern that the legislation was directed at Bollen, motivated by a pecuniary interest in his successful practice at Port Adelaide. As one member pointed out, "for years other doctors in the district had tried to stop Dr Bollen from practising but without success". ${ }^{97}$ Cases of Medical Board opposition to other German practitioners (Mr F A W Doenan and Dr Hollmann) were cited. More pragmatic concerns were expressed about the widespread population of South Australia and the lack of doctors; under these conditions there should be a degree of latitude so as to allow competent persons-who "were better medical practitioners in the medical sense than those who were in the legal sense" 98 - to carry on their practice without diplomas.

There was also concern about the amount of power given the Board and it was observed that "their object was to make the medical profession as exclusive as possible". 99 More particular concern was aired about the Board's treatment of Bollen. "When called upon to do so the Board had failed lamentably to discover what were the facts of a case and what was the law. With their late experience of the Board in the case of Dr Bollen [Mr Kingston] did not think they should grant such power to the Board". ${ }^{100}$

Notwithstanding the opposition, the Medical Act Amendment Bill, designed specifically to prevent the registration of foreign-qualified practitioners in South Australia was passed. Henceforth, those entitled for registration had either to be qualified to register in Britain, or to be graduates (doctors or bachelors) of medicine from an Australian university, or, in the opinion of the Medical Board, have equivalent qualifications. However, the state's action was not a consequence of allopathy's appeal to science. Rather, the outcome was a pragmatic one, based on the need for practitioners, and the state recognized the profession's claims in return for its delivering the statistical returns necessary to administer the population. The tightening of registration provided the state with a pool of registered practitioners to carry out the necessary requirements of the registration of births and deaths. ${ }^{101}$

\section{Deep Drainage and the Sanitary Engineers}

The claims to scientificity by medicine were also challenged in a debate over the introduction of deep drainage. Central to it was the right to define the cause and nature of disease. This involved both medical practitioners and sanitary engineers. ${ }^{102}$ On another level, it resulted in conflict between the state and the private sector over who should pay for the introduction of deep drainage. The focus of this section of the paper is on the former. The problem was this: would sewers cause even more illness by allowing sewer gas to develop and hence miasma, or would the carrying away of sewage prevent the rise of miasmic influences? ${ }^{103}$ This debate made problematic the whole concept of miasma,

\footnotetext{
${ }^{97}$ SAPD, 1889 , 19 Nov.: 1608.

98 Ibid., 1610.

99 Ibid.

${ }^{100}$ SAPD, 1889, 3 Dec.: 1807.

${ }^{101}$ SAPD, 1889, 12 Nov.: 1518.

102 For similarities with England, see C Lawrence, 'Sanitary reformers and the medical profession in Victorian England', in T Ogawa (ed.), Proceedings of the 5th International Symposium on the
}

\author{
Comparative History of Medicine-East and West, \\ Tokyo, Saikon Pub. Co., 1981, pp 145-68; and with \\ the USA, see J Duffy, 'The American medical \\ profession and public health: from support to \\ ambivalence', Bull. Hist. Med., 1979, 53 (1): 1-22. \\ ${ }^{103}$ See, S Tesh, 'Political ideology and public \\ health in the nineteenth century', Int. J. Health Serv., \\ 1982, 12 (2): $321-42$.
}




\section{Medicine in Nineteenth-Century South Australia}

for it changed the focus from individual disease states to environmental conditions and in turn implicated the state with calls for a building Act, and for the control of water supplies.

In 1849, John Stephens, editor and proprietor of the Adelaide Register and the Adelaide Observer, delivered a three-hour lecture to a packed audience, which effectively started the battle in South Australia between medical conceptions of the causes of illness and those of engineers and the public health movement. He pointed to "those precautions which, to a great extent, render medicine and the medical art unnecessary, and which in general are safe guarantees of a sound constitution and long life". ${ }^{104}$ These factors were pure air and ventilation, light, pure water, wholesome and sufficient food, proper shelter and clothing and surface and underground drainage. Further, ". . . the scavenger who swept the street and cleared the drains did more for the public health than the most skilful physician". ${ }^{105}$ Stephens was quite explicit that it was the social conditions in a community which were most important in any understanding of and attempts to prevent disease. In the presence of "sewers and open cesspools, festering graves and filthy slaughterhouses"106 nothing could contribute more effectively to the health of a city than a complete system of sewage and surface drainage and that "the liability of disease and death is in precise proportion to the neglect of this all important precaution". 107

Stephens shared with his contemporaries an abhorrence of "disease mist", "a compound of dissolving organic particles and putrid smells", 108 and an overriding concern for pure air. For example, J L Hyndman, the Adelaide City Surveyor, published a paper on sewage in 1867 in which he stated:

It is impure air which produces the differences between the health we experience when living in the country and when living in the town ... A certain want of alacrity and readiness on waking from sleep, a sense of ennui and nervousness, with an inclination at times to drink more than one otherwise would of habitual stimulants such as tea, ale, etc. arises entirely from impure air, and were it remedied we should enjoy all that is enjoyable with greater zest, life would be fifty percent better, and death some few percent less than it is now. ${ }^{109}$

At the same time "air" could be used as an explanation for the spread of disease in such a way as to omit the physical environment. The second Report of the Board of Health in 1875 located the cause of typhoid in faecal contamination, but asserted that the means of infection was by air. In its eighth Report, in 1882, the Board documented an overall decrease in the mortality rate, "which may be fairly attributed to sanitary improvements in the construction of dwellings, better water supply and improved drainage". ${ }^{110}$ However, entered under a table titled 'Deaths from Miasmatic Diseases' are figures showing a marked increase in typhoid deaths, from 68 in $1880-81$ to 106 in 1881-82. These, however, are excluded from the realm of environmental or social causation:

It has been stated that the prevalence of typhoid fever is to be traced to the inferior quality of the water supply, but your Board have no evidence of such being the case, but rather that the epidemic

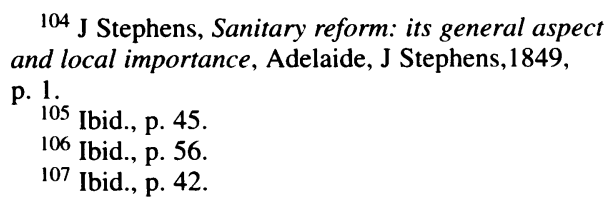

107 Ibid., p. 42.

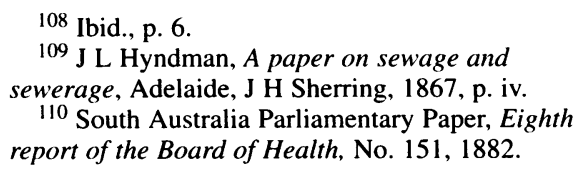

108 Ibid., p. 6.

$109 \mathrm{~J}$ L Hyndman, A paper on sewage and sewerage, Adelaide, J H Sherring, 1867, p. iv.

${ }^{110}$ South Australia Parliamentary Paper, Eighth report of the Board of Health, No. 151, 1882. 


\section{KN White}

of typhoid is to a greater extent atmospheric and not confined to the area supplied by Adelaide and Suburban waterworks. ${ }^{111}$

There is no breakdown by district of the occurrence of the typhoid epidemic: it is not likely that the distribution was any different from that commented on in the Fifteenth report of the Central Board of Health in 1888-89. On that occasion no district in the colony reported more than five deaths, while Adelaide City registered nineteen.

The response of the medical profession to the alleged causal role of sewage was ambiguous; in the light of miasmatic theories of disease, sewer air or sewer gas was obviously implicated. However, while the proposed aetiology of disease remained as pervasive as "air" (or temperature), then it was open to all comers to define and offer suggestions for the amelioration of the conditions giving rise to disease. In this case the strongest threat to medical claims to an understanding of disease was offered by the sanitary engineers and it is interesting to trace how the medical profession attempted to define "air" in such a way as to make it inaccessible to either the engineers or the public health movement.

In following the work of Allan Campbell, we find, in 1878, his theory that it is particles in the air that are responsible for milk souring in the warm weather. These same particles cause disease. Where do they come from? "... they come from the surface of the ground, from the water as it rises in the air, the smoke, the factories, the walls of buildings, the gutters in front of your houses and the yards behind-in a word from every object around you". ${ }^{112}$ Campbell acknowledged that the sewerage system had been very effective in removing wastes, but, he inquired, what of the air that has come into contact with it? Campbell quoted Baldwin Latham's work on sanitary engineering:

Moreover it must be admitted that, as contact with foul matter will pollute those that touch it, so air brought into contact with the foul matters conveyed by sewers will contract impurities which will be increased by the organic vapours constantly being given off by sewage, and in some cases by organised germs and other matters found floating in the air of sewers. ${ }^{113}$

What Campbell did with this extract was to use it as a basis for a distinction between "sewer air" and "sewer gas". Campbell's use of these terms was inconsistent, for in one publication sewer gas was the result of decomposing sewage; ${ }^{114}$ and sewer air was foul or stagnant air that had been shut away under any conditions for a period of time. He might have been expected to identify sewer gas as playing a role in the aetiology of disease, but in another publication he pointed to sewer air. It is not the terminological slips that are important, rather that Campbell was trying to create a definition of a particular object which was solely the province of the medical profession. He asserted that sewer air must be assumed to be an agent in the causation of disease until those "disease germs that produce enteric fever, diphtheria and all their kindred diseases are measured . . . Further no greater mistake could be made than to risk the public health by discounting the power of sewer air". 115

Knowledge of the problem of disease, the role of sewer air, and the role of germs, could be known only by the medical profession. He argued that engineers' "work lies with

111 Ibid., p. 8.

112 Campbell, op. cit., note 33 above, p. 12.

114 Ibid.

113 Campbell, op. cit., note 36 above, p. 2.

115 Ibid., pp. 3-4. 


\section{Medicine in Nineteenth-Century South Australia}

immediate and sensible effects" while the doctors' knowledge is based on an "investigation of a subtle and prolonged character". "Our practice" he proclaimed, "must be the outcome of theory, or our work is doomed", and only the medical profession had access to this theory. ${ }^{116}$

In a paper entitled 'The people's health' published in 1898, Campbell claimed the domain of public health for the medical profession. It was, he stated, only as the theoretical insights had been developed by doctors and incorporated into public health legislation that public hygiene had improved. The basis of this claim-the theoretical insight-was the germ theory of disease:

Hypothesis has given way to fact and uncertainty to knowledge. The secret has been discovered and new light has at last been shed on a hitherto dark and mysterious page of nature. To the germ theory of disease belongs the credit for this transformation. But it is no longer a theory: it has become a science. Furthermore such knowledge has been obtained only by patient and self sacrificing labour, and it alone can safely guide legislation. It can no longer be left out in public health administration. ${ }^{117}$

However, defining and controlling public health was not effected that easily. Nor was germ theory readily accepted as the fundamental basis of medical science, and thus the justification for its role in public health.

\section{The Germ Theory}

In the debate on the 1898 Public Health Act, Campbell called for compulsory public health measures on the grounds that:

There was a time when doubt and difficulty surrounded every great problem in sanitation and hygiene-when climate, winds, rains, droughts, magnetic changes and lastly providential visitations were involved to account for epidemics and large invasions of disease. All that had gone now, and we could speak with definiteness and decision. There was no longer any room left for the climate, winds and drought question, far less for providential visitations, which were now known to be simply records of broken natural laws. Bacteriology would not admit of doubt on these heads, and speaking to the public with authority it demanded a recognition of its truths, or it proclaimed in the same breath the absolute certainty of disease. It was this certainty that put the demands of public health on a footing today it never held before. ${ }^{118}$

This position was not accepted at face value and a good deal of discussion took place. ${ }^{119}$ It was pointed out that, to anyone who had read Lucretius, germs and atoms were not new and Campbell's belief blew a simple fact out of proportion. ${ }^{120}$ The medical profession was accused of generating a "germ scare" to further its own interests and not the public's health:

A section of the medical profession had recently come to the conclusion that every other man and woman would die of consumption in the next three weeks. A lot of these alleged discoveries were

116 Ibid., p. 3.

117 Campbell, op. cit., note 35 above.

118 SAPD, 1897, 24 Aug.: 178.

119 For an analysis of the English case, see J K

Crellin, 'The dawn of the germ theory: particles, infection and biology', in F N Poynter (ed.), Medicine and science in the 1860s, London, Wellcome Institute of the History of Medicine, 1968.

${ }^{120}$ SAPD, 1898, 2 Dec.: 1013. 


\section{KN White}

nothing but theories, and we generally had one about every five years. ... Most of the inventors of these germ theories only wanted to get their names up and make money. ${ }^{121}$

By focusing on germs the profession was accused, by both those in favour of public health legislation and those against it, of obscuring the real causes of the disease, namely, the environmental conditions:

They must judge from facts and not theories, and they should consider the conditions under which people lived when legislating in a matter of this kind . . . it was surprising how well our grandmothers got on without scientific treatment . . which was deemed so essential today. ${ }^{122}$

However, the focus on the environment and sanitation as the basis of public health left little room for the medical practitioner. In a debate about whether cremation was more sanitary than burial and prevention better than cure, it was argued that:

There was a great difference between the general practitioner and the thoughtful man who devoted his attention to sanitary study, and it frequently happened that the nurse and sanitary science did more for the preservation of life than the three doses of medicine a day. ${ }^{123}$

Other opponents of public health admitted that the germ theory might be correct, but argued that to save the sick was to threaten the genetic fitness of the race. In other words, it would contravene "that great natural law, the survival of the fittest, which operated in a beneficial manner, although at times rather severely". ${ }^{24}$ Against these reactions the medical profession had to back-pedal on the role of microbes. As Campbell argued, he was not

... quite so gone on microbes as to think they were in perpetual danger of being attacked by them. He did not quite believe that the mother should have present to her mind when she kissed the lips of her baby, or the husband and lover the cheeks of his wife or sweetheart, the danger he or she runs from microbes. He did not think it was necessary to pass over one's face, or the face of the baby or the wife, a towel dipped in a solution of corrosive sublimate, or carbolic acid, or some other germicide, as they said goodbye in the morning. These germs might be everywhere but they were not in danger of being eaten up by them. It was not necessary, whatever might be the consciousness of the bacteriologist or the proclamation of science, to shake hands with a friend with a pair of antiseptic gloves on, or to abolish easy chairs and cretonne covered couches and curtains and carpets. ${ }^{125}$

Supporters of medical practitioners came to their aid claiming that it was not selfinterest that motivated their researches but "kindly thought for their fellow man". ${ }^{126}$ The profession also went on the offensive, attacking public health legislation on the grounds that it was poorly conceived in the light of medical knowledge. One such example was Campbell's motion to include sore throats in the list of infectious diseases during the debate on the 1896 Health Act. ${ }^{127}$ The logic of Campbell's attack was that unless medical knowledge and particularly bacteriological knowledge were taken into account public health legislation would end up with ludicrous clauses in it. Hand in hand with this argument went the veiled threat that the profession would withdraw its services to the state unless suitable rewards were forthcoming. ${ }^{128}$

121 Ibid., 1010.

122 Ibid.

123 SAPD, 1891, 19 Aug.: 810.

124 SAPD, 1898, 2 Dec.: 1012.
125 SAPD, 1897, 24 Jan.: 180.

126 SAPD, 1898, 2 Dec.: 1011.

127 SAPD, 1896, 20 Oct.: 229.

128 Ibid. 


\section{Medicine in Nineteenth-Century South Australia}

\section{Conclusion}

Accounts of nineteenth-century medical professionalization identify the role that science played in it, either as a self-evident truth, or as a key variable whereby medicine hijacked the prestige of science to achieve social advancement. The province of South Australia provides a unique environment in which to examine these arguments, showing as it does that where medicine was empirically and scientifically grounded-in statistical surveys of outbreaks of disease-it came into conflict with the individualism of liberalism. On the other side, medicine's claims to be a science were roundly rejected in a colonial society which disparaged the old corporatist basis of social privilege. The fact that the medical practitioners who went to South Australia were not all orthodox allopaths, and that their leaders were unashamed homoeopaths, compounded all the problems, and frequently left the profession hoist on its own petard. What is clear from this study is that the professionalization process was shaped by the political ideology of the colony, factors internal to the profession, the administrative requirements of the state, and contested explanations of disease from other nascent professional groups. Standing behind these specific social factors was the spectre of classical liberal doctrines of freedom of choice and individualism, which, while modified by the colonial environment, still pressed hard against the profession's claims to social closure on the basis of the scientific nature of its practice.

The political ideology of the colonial society was a mixture of an explicit role for the state in social life, a Chartist political backdrop, and a mercantilist ethos. As one commentator has pointed out in discussing colonial Australia: "the discussion of the grand principles of conservative and radical political philosophy - of the rights of men and the rights of society-largely became redundant". ${ }^{129}$ In this context there was a far more pragmatic response to the nascent profession's demands for the elimination of unqualified practice. The state, for example, used qualified or unqualified practitioners depending on its requirements to cover a large geographical area to obtain returns on births and deaths.

Those aspects of liberalism that the colonial founders adhered to-free choice and individualism-mitigated against the profession's attempt to gain a monopoly of practice. In the colonial environment these beliefs were fleshed out materially by the fact that within the profession renegades were not alone in practising homoeopathy, its leading members did so as well. This undermined any claim to scientificity as a basis for professionalization and in fact meant that defenders of labour-market closure had to skirt around the topic of specific qualifications.

Thus the claim to scientificity was on shaky ground, made even shakier by sanitary engineers and public health reformers who were vocal and well organized in their opposition to the profession's claims to understand disease. In addition, medical practitioners who were aware of the social patterning of disease sought to convince their colleagues that, for the good of the people, legislation should be enacted overriding individual rights. This combination weakened the appeal to a factitious science. Thus the scientifically and epidemiological sound parts of medicine gave strength to the profession's opponents rather than to its supporters. Even when the germ theory of disease was put forward forcefully by Campbell, he had to back away because of the derision it aroused in the colony.

129 T Duncan and J Fogarty, Australia and Argentina: on parallel paths, Carlton, Vic., Melbourne University Press, 1984, p. 12. 